\title{
Synthesis and Film Formation of Poly(phenylene sulfide) Dendrimers and Dendrons
}

\author{
Omprakash Yemul, ${ }^{1}$ Masaki UjIHARA, ${ }^{2}$ Norio MAKI, ${ }^{2}$ and Toyoko IMAE ${ }^{1,2, \dagger}$ \\ ${ }^{1}$ Research Center for Materials Science, Nagoya University, Chikusa, Nagoya 464-8602, Japan \\ ${ }^{2}$ Graduate School of Science, Nagoya University, Chikusa, Nagoya 464-8602, Japan
}

(Received September 6, 2004; Accepted October 26, 2004; Published February 15, 2005)

\begin{abstract}
Poly(phenylene sulfide) dendrimers up to fourth generation were synthesized by divergent method from 1,3,5-tris(4-chloro-phenylene-1-thio)benzene. All the dendrimers are soluble in polar organic solvents at room temperature. The chemical structures at the synthesis steps were confirmed by spectroscopic method. X-Ray diffraction study revealed that all dendrimers are semi-crystalline in nature. Carboxy focal poly(phenylene sulfide) dendrons were synthesized up to second generation by divergent method from 3,5-dichlorobenzoicacid. On surface pressure-area isotherm at air-water interface, third generation poly(phenylene sulfide) dendrimer displayed hysteresis. Its occupied surface area was smaller than the calculated values as well as a case of second generation poly(phenylene sulfide) dendron. Atomic force microscopic images of their LB films presented accumulation and aggregation of molecular layers. On the other hand, adsorption films of dendrimer and dendron were fundamentally monolayer. Molecular arrangements in the LB and adsorption films and the driving forces of the film formation were discussed.

[DOI 10.1295/polymj.37.82]

KEY WORDS Poly(phenylene sulfide) / Dendrimer / Dendron / Synthesis / Characterization / Adsorption / Film /
\end{abstract}

In recent years there has been interest in the development of rational synthesis route to polymers having architectures other than linear chains, such as ladder, star, comb, hyperbranched polymers and dendrimers. ${ }^{1}$ Highly branched molecules such as dendrimers and hyperbranched polymers attract the attention of various research groups because of their unique physical and chemical characteristics. ${ }^{2-4}$ Both divergent ${ }^{5-7}$ and convergent ${ }^{8,9}$ approaches produce well-defined nanostructures.

Novel poly(phenylene sulfide) dendrimers/dendrons will open a new era in supramolecular chemistry. ${ }^{10,11}$ They have variety of applications from multisite catalyst, ${ }^{12}$ multivalent glycodendrimers, ${ }^{13,14}$ fluorescent biosensors, new conducting materials, ${ }^{15}$ to best candidates for self assembled monolayers on gold and silver surfaces for smart materials. ${ }^{16,17}$ Researchers have tried to synthesize the hyperbranched poly(phenylene sulfide), ${ }^{18,19}$ phenylene sulfide molecular asterisks $^{20,21}$ oligo ( $m$-phenylene sulfide) $\mathrm{s}^{22-24}$ and solid supported poly(thioether) dendron. ${ }^{25}$

In present work we report the synthesis of novel poly(phenylene sulfide) dendrimers and carboxy focal poly(phenylene sulfide) dendrons by nucleophilic synthesis method and film formation of dendrimers and dendrons on mica surface.

\section{EXPERIMENTAL}

\section{Materials}

4-Chlorothiophenol, 1,3,5-tribromobenzene, 1,3,5trichlorobenzene, 3,5-dichlorobenzoicacid, sodium hydrosulfide, 3,5-dichlorobromobenzene, $N, N^{\prime}$-dimethylacetamide, lithium sulfide, $N$-methyl pyrrolidone, methanol and other chemicals were procured from either Aldrich Chemical Co. or Tokyo Kasei Kogyo Chemicals and used without further purification.

\section{Synthesis of Poly(phenylene sulfide) Dendrimers}

1,3,5-Tris(4-chlorophenyl-1-thio)benzene [Core I]. 1,3,5-Tris(4-chlorophenyl-1-thio)benzene was synthesized from 1,3,5-tribromobenzene through nucleophilic substitution. ${ }^{18,19}$ A two-neck round bottom flask equipped with nitrogen gas inlet and reflux condenser was charged with $12.8 \mathrm{~g}(10 \mathrm{mmol})$ of 1,3,5-tribromobenzene, $23.8 \mathrm{~g}(30 \mathrm{mmol})$ of 4-chlorothiophenolsodiumsalt and $50 \mathrm{~cm}^{3}$ of dimethylacetamide solvent. Nitrogen gas (99.9\%) was bubbled through the solution to completely displace air. The reaction mixture was gradually heated up to $150^{\circ} \mathrm{C}$, maintained for $6 \mathrm{~h}$ under stirring, and then cooled to room temperature. The product was extracted in chloroform. It was further recrystallized in ethylacetate/hexane (1:4) solvent mixture and dried at $25^{\circ} \mathrm{C}$ till constant

${ }^{\dagger}$ To whom correspondence should be addressed (Tel: +81-52-789-5911, Fax: +81-52-789-5912, E-mail: imae@ nano.chem.nagoya-u.ac.jp). 
weight. The yield was $70 \%$. It was characterized as follows. $\mathrm{mp} 280^{\circ} \mathrm{C}$; IR (KBr): $3110,3072,2362$, 2340, 1739, 1714, 1556, 1527, 1405, 1374, 1351, 1096, 846, 744, $656 \mathrm{~cm}^{-1}$; Elemental anal. $\mathrm{C}_{24} \mathrm{H}_{15}$ $\mathrm{S}_{3} \mathrm{Cl}_{3}$ (FW 505) Calcd for C 56.97, H 2.98, S 19.01; Found C 56.10, H 2.51, S 18.42; UV-vis $\left(\mathrm{CHCl}_{3}\right)$ $\lambda_{\max }(\varepsilon)=248 \mathrm{~nm}\left(4121 \mathrm{~cm}^{2} \mathrm{~mol}^{-1}\right), 275 \mathrm{~nm}$; Fluorescence emission $\left(\mathrm{CH}_{2} \mathrm{Cl}_{2}\right) \lambda_{\max }=396 \mathrm{~nm} ;{ }^{1} \mathrm{H}$ NMR $\left(500 \mathrm{MHz}, \mathrm{CDCl}_{3}\right)$ 7.75-7.60 (d, 12H), 7.55-7.45 ppm (s, 3H).

[Core II]. To a thick walled pressure tube, $0.50 \mathrm{~g}$

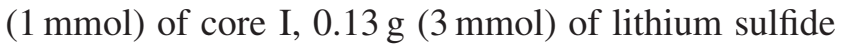
$\left(\mathrm{Li}_{2} \mathrm{~S}\right), 0.543 \mathrm{~g}$ (3 mmol) of 1,3,5-trichlorobenzene and $10 \mathrm{~cm}^{3}$ of $N$-methylpyrrolidone were taken. Nitrogen gas was bubbled through the mixture to remove all air inside, and the tube was held airtight by proper sealing. The tube was heated at $180^{\circ} \mathrm{C}$ in thermostatically controlled oil bath for $6 \mathrm{~h}$. Then it was cooled to room temperature and the reaction mixture was poured into nitric acid (5 vol\%) in methanol to quantitatively precipitate the solid. The solid was filtered, washed with warm distilled water and methanol to remove excess reactants and side products. It was further recrystallized in chloroform/hexane (1:4) solvent mixture and dried at $25^{\circ} \mathrm{C}$ till constant weight. The yield was $65 \%$. The solid product was characterized. IR (KBr): 3062, 1688, 1547, 1403, 1284, 1136, $1095,987,850,796,756,673 \mathrm{~cm}^{-1}$; Elemental anal. $\mathrm{C}_{42} \mathrm{H}_{24} \mathrm{~S}_{6} \mathrm{Cl}_{6}(\mathrm{FW}=933)$ Calcd for C 54.02, H 2.59, S 20.60; Found C 53.36, H 2.10, S 19.49; UV-vis $\left(\mathrm{CHCl}_{3}\right) \lambda_{\max }(\varepsilon)=250 \mathrm{~nm}\left(9569 \mathrm{~cm}^{2} \mathrm{~mol}^{-1}\right)$; Fluorescence emission $\left(\mathrm{CH}_{2} \mathrm{Cl}_{2}\right) \lambda_{\max }=391 \mathrm{~nm} ;{ }^{1} \mathrm{H}$ NMR $\left(500 \mathrm{MHz}, \mathrm{CDCl}_{3}\right) 7.46-7.45(\mathrm{~d}, 12 \mathrm{H}), 7.36-7.34$ (s, 3H), 7.28-7.27 ppm (s, 9H).

Generation 1 [G1]. Synthesis procedure for generation 1 (G1) was same as above for core II. The reactant molar ratios were as follows; $0.933 \mathrm{~g}(1 \mathrm{mmol})$ of

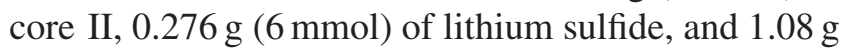
$(6 \mathrm{mmol})$ of 1,3,5-trichlorobenzene. After the product was isolated, it was washed with hot water and methanol to remove side products and reactants and dried at $25^{\circ} \mathrm{C}$ till constant weight. The yield was $85 \%$. IR (KBr): 3060, 2940, 1685, 1648, 1401, 1388, 1289, 1136, 989, 845, 797, $669 \mathrm{~cm}^{-1}$; Elemental anal. $\mathrm{C}_{78} \mathrm{H}_{42} \mathrm{~S}_{12} \mathrm{Cl}_{12}(\mathrm{FW}=1789)$ Calcd for C $52.35, \mathrm{H}$ 2.36, S 21.50, Cl 23.77; Found $\mathrm{C}$ 51.28, H 2.04, $\mathrm{S} 20.16, \mathrm{Cl} 22.09$. UV-vis $\left(\mathrm{CHCl}_{3}\right) \lambda_{\max }=268 \mathrm{~nm}$ $\left(21634 \mathrm{~cm}^{2} \mathrm{~mol}^{-1}\right)$; Fluorescence emission $\left(\mathrm{CH}_{2} \mathrm{Cl}_{2}\right)$ $\lambda_{\max }=386 \mathrm{~nm} ;{ }^{1} \mathrm{H}$ NMR $\left(500 \mathrm{MHz}, \mathrm{CDCl}_{3}\right) 7.36-$ 7.33 (s, 18H), 7.25-7.24 (d, 12H), $7.17 \mathrm{ppm}(\mathrm{s}, 12 \mathrm{H})$.

Generation 2 [G2]. Synthesis and purification procedure for generation 2 (G2) were same as above. The reactant molar ratios were as follows; $1.789 \mathrm{~g}$

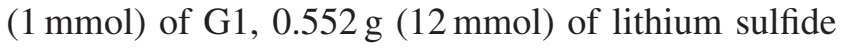

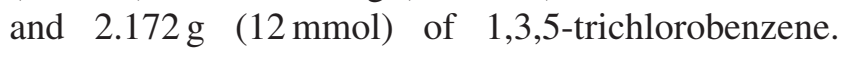

The yield was 65\%. IR (KBr): 3062, 1717, 1548, 1403, 1291, 1137, 1100, 990, 845, 799, $670 \mathrm{~cm}^{-1}$; Elemental anal. $\mathrm{C}_{150} \mathrm{H}_{78} \mathrm{~S}_{24} \mathrm{Cl}_{24}(\mathrm{FW}=3500)$ Calcd for $\mathrm{C} 51.46, \mathrm{H} 2.24, \mathrm{~S} 21.98, \mathrm{Cl} 24.30$; Found $\mathrm{C}$ 50.19, H 2.10, S 20.96, Cl 23.78; UV-vis $\left(\mathrm{CHCl}_{3}\right)$ $\lambda_{\max }(\varepsilon)=266 \mathrm{~nm} \quad\left(30854 \mathrm{~cm}^{2} \mathrm{~mol}^{-1}\right)$; Fluorescence emission $\left(\mathrm{CH}_{2} \mathrm{Cl}_{2}\right) \quad \lambda_{\max }=381 \mathrm{~nm} ;{ }^{1} \mathrm{H}$ NMR $(500$ $\left.\mathrm{MHz}, \mathrm{CDCl}_{3}\right) 7.32-7.31(\mathrm{~d}, 12 \mathrm{H}), 7.26(\mathrm{~s}, 24 \mathrm{H})$, $7.25(\mathrm{~s}, 12 \mathrm{H}), 7.24 \mathrm{ppm}(\mathrm{s}, 30 \mathrm{H})$.

Generation 3 [G3]. Synthesis and purification procedure for generation 3 (G3) were same as above. The reactant molar ratios were as follows; $0.350 \mathrm{~g}$ ( $1 \mathrm{mmol})$ of $\mathrm{G} 2,0.110 \mathrm{~g}(24 \mathrm{mmol})$ of lithium sulfide, $0.434 \mathrm{~g}(24 \mathrm{mmol})$ of 1,3,5-trichlorobenzene. The yield was $60 \%$. IR (KBr): 3109, 3058, 1686, 1545, 1388, 1289, 1135, 1099, 989, 845, 796, $670 \mathrm{~cm}^{-1}$; Elemental anal. $\mathrm{C}_{249} \mathrm{H}_{150} \mathrm{~S}_{48} \mathrm{Cl}_{48}(\mathrm{FW}=6382)$ Calcd for $\mathrm{C} 46.85, \mathrm{H} 2.36, \mathrm{~S} 24.11, \mathrm{Cl} 26.66$; Found C 45.12, H 2.03, S 22.58, Cl 25.98.; UV-vis $\left(\mathrm{CHCl}_{3}\right)$ $\lambda_{\max }(\varepsilon)=274 \mathrm{~nm}\left(42249 \mathrm{~cm}^{2} \mathrm{~mol}^{-1}\right)$; Fluorescence emission $\left(\mathrm{CH}_{2} \mathrm{Cl}_{2}\right) \quad \lambda_{\max }=377 \mathrm{~nm} ;{ }^{1} \mathrm{H}$ NMR $\quad(500$ $\left.\mathrm{MHz}, \mathrm{CDCl}_{3}\right) 7.32-7.31$ (d, 12H), $7.25(\mathrm{~s}, 72 \mathrm{H})$, $7.24 \mathrm{ppm}(\mathrm{s}, 66 \mathrm{H})$.

Generation 4 [G4]. Synthesis and purification procedure for generation 4 (G4) were same as above. The reactant molar ratios were as follows; $0.638 \mathrm{~g}$ ( $1 \mathrm{mmol})$ of $\mathrm{G} 3,0.220 \mathrm{~g}(48 \mathrm{mmol})$ of lithium sulfide, $0.868 \mathrm{~g}$ (48 mmol) of 1,3,5-trichlorobenzene. The yield was $80 \%$. IR (KBr): 3109, 3059, 1689, 1556, $1540,1389,1289,1135,1100,989,845,798$, $670 \mathrm{~cm}^{-1}$; Elemental anal. $\mathrm{C}_{582} \mathrm{H}_{294} \mathrm{~S}_{96} \mathrm{Cl}_{96}(\mathrm{FW}=$ 13768) Calcd for $\mathrm{C} 50.77, \mathrm{H} 2.15, \mathrm{~S} 22.35$, $\mathrm{Cl}$ 24.71.; Found $\mathrm{C} 49.35, \mathrm{H} 2.02, \mathrm{~S} 21.06, \mathrm{Cl}$ 23.58.; UV-vis $\left(\mathrm{CHCl}_{3}\right) \lambda_{\max }(\varepsilon)=275 \mathrm{~nm} \quad(55249$ $\left.\mathrm{cm}^{2} \mathrm{~mol}^{-1}\right)$; Fluorescence emission $\left(\mathrm{CH}_{2} \mathrm{Cl}_{2}\right) \lambda_{\max }=$ $375 \mathrm{~nm} ;{ }^{1} \mathrm{H}$ NMR $\left(500 \mathrm{MHz}, \mathrm{CDCl}_{3}\right) 7.32(\mathrm{~d}, 12 \mathrm{H})$, 7.26 (s, 120H), $7.24 \mathrm{ppm}(\mathrm{s}, 162 \mathrm{H})$.

\section{Synthesis of Carboxy Focal Phenylene Sulfide Den- dron}

Synthesis of 3,5-Dithiobenzoicacid (Dithiol-1). To a thick walled pressure tube, $1.91 \mathrm{~g}(10 \mathrm{mmol})$ of 3,5dichlorobenzeneacid, $1.60 \mathrm{~g}$ ( $22 \mathrm{mmol})$ of sodium hydrosulfide and $10 \mathrm{~cm}^{3}$ of $N$-methyl pyrrolidone were taken. Nitrogen gas was bubbled through the mixture to remove all air inside and the tube was held airtight by proper sealing. The tube was heated at $180^{\circ} \mathrm{C}$ in thermostatically controlled oil bath for $6 \mathrm{~h}$. Then it was cooled to room temperature and the reaction mixture was poured into dilute nitric acid $(5 \mathrm{vol} \%)$ for quantitative precipitation. The precipitated solid was filtered, washed with warm distilled water to remove excess reactants and side products. It was further recrystallized in chloroform/hexane (1:4) solvent mixture and dried at $25^{\circ} \mathrm{C}$ till constant weight. The yield 
was $85 \%$. IR (KBr): 3086, 3003, 2555, 1708, 1571, $1449,1426,1405,1300,1291,1239,1166,925$, 909, 877, 807, 770, 709, $659 \mathrm{~cm}^{-1}$; Elemental anal. $\mathrm{C}_{7} \mathrm{H}_{6} \mathrm{~S}_{2} \mathrm{O}_{2}(\mathrm{FW}=186)$ Calcd for $\mathrm{C} 45.14, \mathrm{H} 3.25$; Found C 45.00, H 3.35; UV-vis $\left(\mathrm{CHCl}_{3}\right) \lambda_{\max }(\varepsilon)=$ 248, 287, $298 \mathrm{~nm}\left(3952 \mathrm{~cm}^{2} \mathrm{~mol}^{-1}\right)$; Fluorescence emission $\left(\mathrm{CH}_{2} \mathrm{Cl}_{2}\right) \quad \lambda_{\max }=390 \mathrm{~nm} ;{ }^{1} \mathrm{H}$ NMR $(500$ $\left.\mathrm{MHz}, \mathrm{CDCl}_{3}\right) 10.3(1 \mathrm{H}), 7.95(\mathrm{~d}, 2 \mathrm{H}), 7.58(\mathrm{t}, 1 \mathrm{H})$, $3.91 \mathrm{ppm}(\mathrm{s}, 2 \mathrm{H})$.

Synthesis of Dendron 1 (den-1). To a two neck round bottom flask equipped with nitrogen gas inlet and reflux condenser with magnetic stirrer was charged with $4.52 \mathrm{~g}(20 \mathrm{mmol})$ of 3,5-dichloro-1-bromobenzene, $2.49 \mathrm{~g}(10 \mathrm{mmol})$ sodium salt of 3,5-dithiobenzoicacid and $50 \mathrm{~cm}^{3}$ of dimethylacetamide solvent. Nitrogen gas (99.9\%) was bubbled through the solution to completely displace air. The reaction mixture was gradually heated up to $150{ }^{\circ} \mathrm{C}$, kept for $6 \mathrm{~h}$. After cooling the reaction mixture, product was extracted in chloroform. It was further recrystallized in ethyl acetate/hexane (1:4) and dried (yield 90\%). It was further characterized as follows: IR (KBr): 3419, 3060, 2940, 1707, 1546, 1401, 1388, 1289, 1136, 1099, 989, 845, 797, $669 \mathrm{~cm}^{-1}$; Elemental anal. $\mathrm{C}_{19} \mathrm{H}_{10} \mathrm{~S}_{2} \mathrm{Cl}_{4} \mathrm{O}_{4}(\mathrm{FW}$ 476) Calcd for $\mathrm{C} 47.92, \mathrm{H} 2.12$, S 12.61; Found C 46.11, H 2.24, S 12.83; UV-vis $\left(\mathrm{CHCl}_{3}\right) \lambda_{\max }(\varepsilon)=$ 241, 262, $288 \mathrm{~nm}\left(4560 \mathrm{~cm}^{2} \mathrm{~mol}^{-1}\right)$; Fluorescence emission $\left(\mathrm{CH}_{2} \mathrm{Cl}_{2}\right) \quad \lambda_{\max }=387 \mathrm{~nm} ;{ }^{1} \mathrm{H}$ NMR $(500$ $\left.\mathrm{MHz}, \mathrm{CDCl}_{3}\right) 10.2(1 \mathrm{H}), 7.39(\mathrm{~s}, 2 \mathrm{H}), 7.32-7.25$ (m, 4H), 7.24-7.21 (m, 2H), $7.17(\mathrm{~s}, 1 \mathrm{H})$. Molecular weight by titration with standard alkali. Calcd 476 Obsd 475.

Synthesis of dithiol-2. Synthesis and purification procedure for dithiol-2 were same as for dithiol-1 above. The reactant molar ratios were as follows; $4.76 \mathrm{~g}(10 \mathrm{mmol})$ of den- $1,3.10 \mathrm{~g}(42 \mathrm{mmol})$ of sodium hydrosulfide and $10 \mathrm{~cm}^{3}$ of $N$-methylpyrrolidone. The yield was $60 \%$. IR (KBr): 3085, 2821, 2556, 1701, 1570, 1449, 1406, 1301, 1292, 1239, 1166, 927, 909, 878, 808, 770, 709, $659 \mathrm{~cm}^{-1}$; Elemental anal. $\mathrm{C}_{19} \mathrm{H}_{14} \mathrm{~S}_{6} \mathrm{O}_{2}(\mathrm{FW}=466)$ Calcd for C 48.90, H 3.02; Found C 47.90, H 3.02; UV-vis $\left(\mathrm{CHCl}_{3}\right) \lambda_{\max }(\varepsilon)=261,285 \mathrm{~nm}\left(8962 \mathrm{~cm}^{2} \mathrm{~mol}^{-1}\right)$; Fluorescence emission $\left(\mathrm{CH}_{2} \mathrm{Cl}_{2}\right) \quad \lambda_{\max }=383 \mathrm{~nm}$; ${ }^{1} \mathrm{H}$ NMR $\left(500 \mathrm{MHz}, \mathrm{CDCl}_{3}\right) 10.3(1 \mathrm{H}), 7.95-7.94$ (d, 3H), 7.58-7.57 (t, 6H), $3.95 \mathrm{ppm}(\mathrm{m}, 4 \mathrm{H})$.

Synthesis of dendron 2 (den-2). Synthesis and purification procedure for den-2 were same as for den-1 above. The reactant molar ratios were as follows; $5.71 \mathrm{~g}(10 \mathrm{mmol})$ of sodium salt of dithiol-2, $9.04 \mathrm{~g}$ $(40 \mathrm{mmol})$ of 3,5-dichloro-1-bromobenzene and 50 $\mathrm{cm}^{3}$ of dimethylacetamide. The yield was $90 \% . \mathrm{mp}$ $260^{\circ} \mathrm{C}$; IR (KBr): 3452, 3114, 3067, 1703, 1550, 1405, 1287, 1139, 1100, 1097, 990, 845, 799, 676, $666 \mathrm{~cm}^{-1}$; Elemental anal. $\mathrm{C}_{43} \mathrm{H}_{22} \mathrm{~S}_{6} \mathrm{Cl}_{8} \mathrm{O}_{2}$ (FW
1046) Calcd for C 49.35, H 2.12, S 18.38; Found C $50.21, \mathrm{H} 2.42, \mathrm{~S} 19.10$; UV-vis $\left(\mathrm{CHCl}_{3}\right) \lambda_{\max }(\varepsilon)=$ $263,286 \mathrm{~nm}\left(9524 \mathrm{~cm}^{2} \mathrm{~mol}^{-1}\right)$; Fluorescence emission $\left(\mathrm{CH}_{2} \mathrm{Cl}_{2}\right) \lambda_{\max }=379 \mathrm{~nm} ;{ }^{1} \mathrm{H}$ NMR $(500 \mathrm{MHz}$, $\left.\mathrm{CDCl}_{3}\right) 10.3(1 \mathrm{H}), 7.32(\mathrm{~s}, 2 \mathrm{H}), 7.31-7.24(\mathrm{~m}, 8 \mathrm{H})$, 7.24-7.17 (m, 7H), $7.16(\mathrm{~s}, 2 \mathrm{H}), 7.15 \mathrm{ppm}(\mathrm{s}, 2 \mathrm{H})$. Molecular weight by titration with standard alkali. Calcd 1046 Obsd 1045.

\section{METHODS}

Fourier transform infrared absorption (FT-IR) spectra were recorded using a Bio-Rad FTS575C FT-IR spectrometer equipped with a cryogenic mercury cadmium telluride (MCT) detector. The spectra were collected with 512 scans at $4 \mathrm{~cm}^{-1}$ resolutions. Elemental analysis was performed on LECO CHN-900 C CHN analyzer. UV-vis absorption spectra were recorded on a Shimadzu UV 2200 spectrometer, while fluorescence spectra were measured on Hitachi F4010 model. The solution $\left(1 \mathrm{mg} / \mathrm{cm}^{3}\right)$ was prepared by dissolving polymer powder in chloroform for UV measurement and in dichloromethane for fluorescence spectra. NMR spectra were recorded on JEOL JNM-L500 in deuterated chloroform. X-Ray diffraction (XRD) measurements were carried out on Rigaku RINT $2100 \mathrm{~V}$ X-ray diffractometer using scanning rate $0.5^{\circ} / \mathrm{min}$. The radiation was used $\mathrm{Cu} \mathrm{K} \alpha(\lambda=$ $1.5405 \AA$ ). Samples were prepared by spreading polymer on silicon substrate. Surface pressure measurements and LB film preparation were carried out on a LB film deposition apparatus (Nippon Laser \& Electronics Lab.). A $0.48 \mathrm{mM}$ chloroform (spectroscopic grade) solution of polymer was spread onto the aqueous subphase maintained at $25 \pm 0.5{ }^{\circ} \mathrm{C}$ by a water circulator. After evaporation of solvent $(30 \mathrm{~min})$ the monolayer was compressed at a constant rate of 25 $\mathrm{cm}^{2} \mathrm{~min}^{-1}$ up to the surface pressure of $35 \mathrm{mN} \mathrm{m}^{-1}$. After being allowed to equilibrate for $30 \mathrm{~min}$ at the above surface pressure, the condensed films were transferred onto mica by raising the immersed substrate at rate of $0.2 \mathrm{~cm} \mathrm{~min}^{-1}$ by using the ( $Z$ axis) vertical lifting technique. The substrate was fixed vertically touched to the surface of the Langmuir film, and then lifted to the air phase. After the LB film was dried in desiccator, the deposited amount was confirmed from the $\pi-\mathrm{A}$ isotherm. The transfer ratio was found to be nearly unity throughout the experiment. AFM observations were performed at room temperature in the tapping mode on an AFM Nanoscope III (Digital Instruments, Inc.). A crystalline silicon tip on a cantilever was used. The surface roughness was obtained by sectional analysis. All the measurements were carried out at room temperature. 

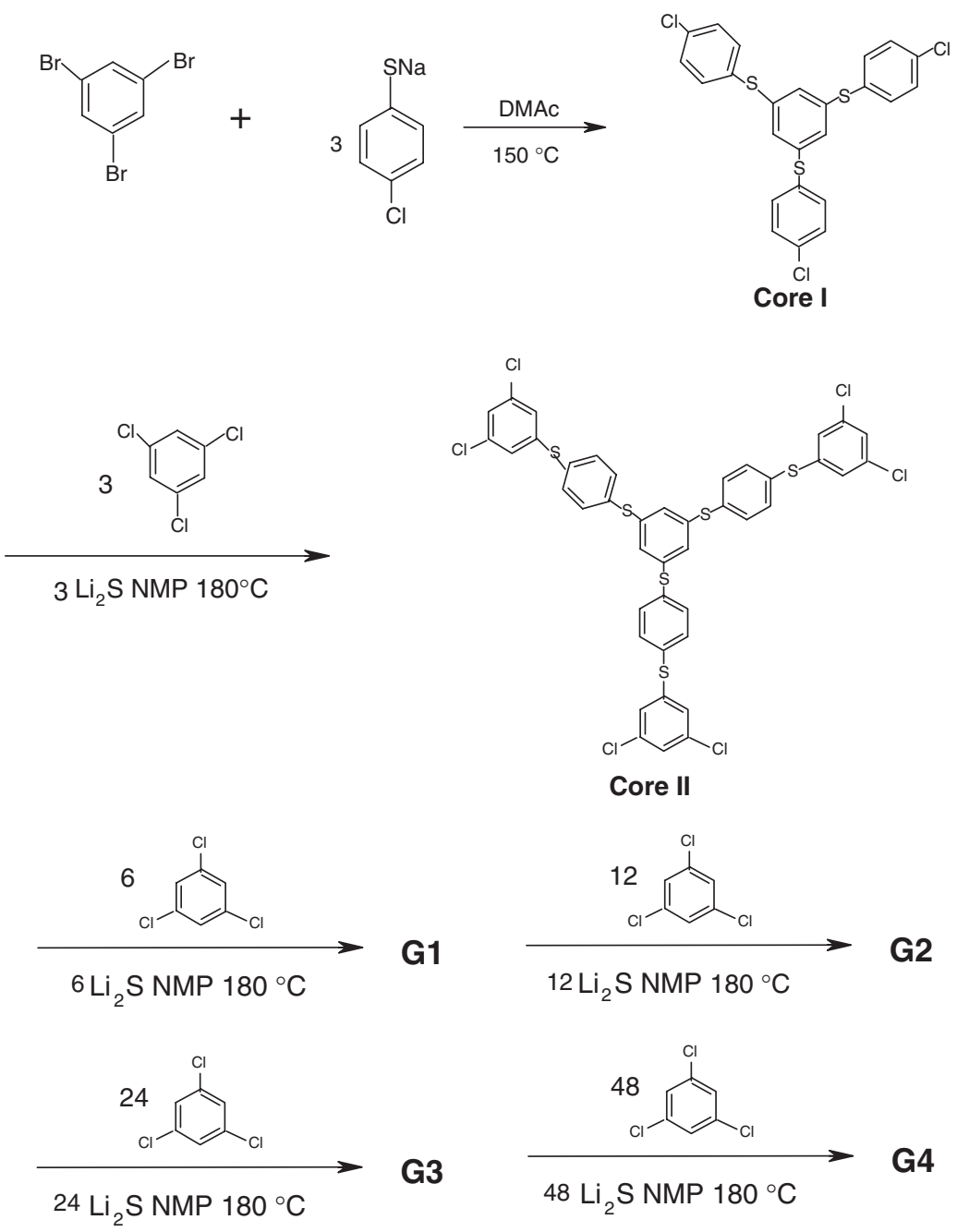

Scheme 1. Synthesis of poly(phenylene sulfide) dendrimers.

\section{RESULTS AND DISCUSSION}

\section{Synthesis of Poly(phenylene sulfide) Dendrimers}

The divergent synthesis method was used to synthesis of poly(phenylene sulfide) dendrimers. 1,3,5-tris(4chlorophenyl-1-thio)benzene was synthesized from 4chlorothiophenoxide with tribromobenzene by nucleophilic substitution reaction as reported elsewhere. ${ }^{18,19}$ It was used as central core (core I) for synthesis of poly(phenylene sulfide) dendrimers: The successive higher generations were further synthesized by reacting the core I with trichlorobenzene and lithium sulfide in polar aprotic solvents such as $N$-methylpyrrolidone at high temperatures. The complete reaction scheme is presented in Scheme 1. The quantitative yield at each step was 60 to $85 \%$.

The UV-vis spectrum of core I displayed a maximum absorption band at $248 \mathrm{~nm}$ assigned to phenylene sulfide and a weak band at $275 \mathrm{~nm}$ assigned to sulfurated benzene core, while its extinction coefficient value is $4121 \mathrm{~cm}^{2} \mathrm{~mol}^{-1}$. The excitation at
$248 \mathrm{~nm}$ produced a maximum fluorescence emission band at $396 \mathrm{~nm}$. UV-vis and fluorescence spectral data of core I, core II, and dendrimers up to fourth generation were presented in Table I. Core II compound displayed an absorption band at $250 \mathrm{~nm}$ and its extinction coefficient of $9569 \mathrm{~cm}^{2} \mathrm{~mol}^{-1}$. Similarly poly(phenylene sulfide) dendrimers (first generation to fourth generation compounds) displayed the absorption band shift from 268 to $275 \mathrm{~nm}$ and their extinction coefficient values increased from 21364 to $55249 \mathrm{~cm}^{2} \mathrm{~mol}^{-1}$. On the other hand, fluorescence emission bands shifted from $386 \mathrm{~nm}$ for first generation to $375 \mathrm{~nm}$ for fourth generation. The UV-vis and fluorescence spectral data are comparable with those of phenylene sulfide molecular asterisk. ${ }^{20,21}$ However, in the present study, the spectral bands are blue-shifted due to small number of phenylene sulfide linkages or groups than that in reported molecular asterisk.

The FT-IR spectrum of tris-1,3,5(4-chlorophenyl-1thio)benzene (core I) shows bands at 1556, 1405, and $1374 \mathrm{~cm}^{-1}$ which are assigned to phenyl ring stretch- 
O. YeMUl et al.

Table I. UV-vis absorption and fluorescence spectra, proton NMR and crystallinity data of poly(phenylene sulfide) dendrimers

\begin{tabular}{|c|c|c|c|c|c|}
\hline Compound & $\begin{array}{c}\mathrm{UV}-\mathrm{vis} \\
\lambda_{\max }(\mathrm{nm})^{\mathrm{a}}\end{array}$ & $\begin{array}{c}\varepsilon \\
\left(\mathrm{cm}^{2} \mathrm{~mol}^{-1}\right)^{\mathrm{a}}\end{array}$ & $\begin{array}{c}\text { Fluorescence } \\
\lambda_{\max }(\mathrm{nm})^{\mathrm{b}}\end{array}$ & $\begin{array}{l}{ }^{1} \mathrm{H} \mathrm{NMR} \\
\delta(\mathrm{ppm})^{\mathrm{c}}\end{array}$ & $\begin{array}{l}\text { Crystallinity } \\
(\%)^{\mathrm{d}}\end{array}$ \\
\hline Core I & $248,275 w$ & 4121 & 396 & $\begin{array}{l}7.75-7.60(\mathrm{~d}, 12 \mathrm{H}), \\
7.55-7.45(\mathrm{~s}, 3 \mathrm{H})\end{array}$ & - \\
\hline Core II & 250 & 9569 & 391 & $\begin{array}{l}7.46-7.45(\mathrm{~d}, 12 \mathrm{H}), \\
7.36-7.34(\mathrm{~s}, 3 \mathrm{H}), \\
7.28-7.27(\mathrm{~s}, 9 \mathrm{H})\end{array}$ & 72 \\
\hline G1 & 268 & 21364 & 386 & $\begin{array}{c}7.36-7.33(\mathrm{~s}, 18 \mathrm{H}), \\
7.25-7.24(\mathrm{~d}, 12 \mathrm{H}), \\
7.17(\mathrm{~s}, 12 \mathrm{H})\end{array}$ & 42 \\
\hline G2 & 266 & 30854 & 381 & $\begin{array}{c}7.32-7.31(\mathrm{~d}, 12 \mathrm{H}), \\
7.26(\mathrm{~s}, 24 \mathrm{H}), \\
7.25(\mathrm{~s}, 12 \mathrm{H}) \\
7.24(\mathrm{~s}, 30 \mathrm{H})\end{array}$ & 34 \\
\hline G3 & 274 & 42249 & 377 & $\begin{array}{c}7.32-7.31(\mathrm{~d}, 12 \mathrm{H}) \\
7.25(\mathrm{~s}, 72 \mathrm{H}) \\
7.24(\mathrm{~s}, 66 \mathrm{H})\end{array}$ & 29 \\
\hline G4 & 275 & 55249 & 375 & $\begin{array}{l}7.32(\mathrm{~d}, 12 \mathrm{H}) \\
7.26(\mathrm{~s}, 120 \mathrm{H}) \\
7.24(\mathrm{~s}, 162 \mathrm{H})\end{array}$ & 25 \\
\hline
\end{tabular}

${ }^{\mathrm{a}} 1 \mathrm{mg} \mathrm{cm}^{-3}$ in chloroform. ${ }^{\mathrm{b}} 1 \mathrm{mg} \mathrm{cm}^{-3}$ in dichloromethane. ${ }^{\mathrm{c}} 1 \mathrm{mg} \mathrm{cm}^{-3}$ in deuterated chloroform. ${ }^{\mathrm{d}}$ Estimated from X-ray diffractogram

ing modes. ${ }^{26}$ The infrared absorption bands in the range of 900 to $700 \mathrm{~cm}^{-1}$ also indicate the aromatic substitution of benzene ring. The band at $1096 \mathrm{~cm}^{-1}$ may be assigned to phenyl chloride stretching mode, since such characteristic band is observed in the spectra of 4-chlorothiophenol. ${ }^{27}$ There is no peak in the range around 2600 to $2550 \mathrm{~cm}^{-1}$, which corresponds to thiol group. Core I is free of oxidized products such as sulfone and sulfoxide since bands assigned to sulfone around 1165, 1325, 1030 and $640 \mathrm{~cm}^{-1}$ and bands assigned to sulfoxide at 1030 to $1000 \mathrm{~cm}^{-1}$ are absent. Thianthrane bands around 1430, 1260 and $880 \mathrm{~cm}^{-1}$ are also absent. Hence, the product is free from cross-linking. The comparable FT-IR spectra of core II and first-fourth generation poly(phenylene sulfide) dendrimers to core I have been presented in Figure 1. The FT-IR spectra show bands of phenyl ring stretching modes at 1556, 1405, $1374 \mathrm{~cm}^{-1}$ and bands of aromatic substitution of benzene ring at $900-700 \mathrm{~cm}^{-1}$. The spectra also present the band assigned to phenyl chloride at $1096 \mathrm{~cm}^{-1}$, implying that terminal groups of dendrimers are chloride functional group. Elemental analysis of PPS dendrimers agrees with theoretical values as expected for the structure.

${ }^{1} \mathrm{H}$ NMR spectrum of core I displays signals at 7.75-7.60 and 7.55-7.45 ppm, corresponding to sulfurated benzene as singlet and phenylene sulfide side arm as doublet, respectively. Reported data of similar compound $^{18}$ presents signals at 7.55-7.20 and 7.15$6.95 \mathrm{ppm}$ which are in good agreement with those of

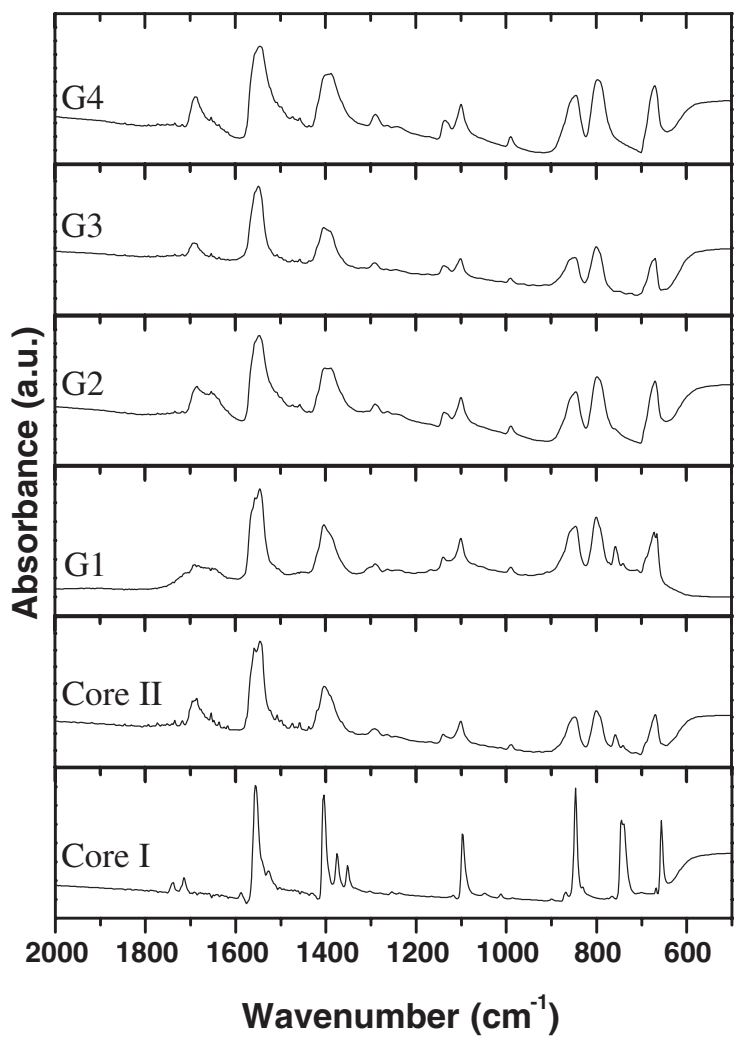

Figure 1. FT-IR spectra of core I to fourth generation poly(phenylene sulfide) dendrimer.

Core I compound. ${ }^{19}$ Similarly, ${ }^{1} \mathrm{H}$ NMR spectra of other compounds (core II to fourth generation poly(phenylene sulfide) dendrimer) present the signals in 
the range of 7.75 to $7.17 \mathrm{ppm}$. Phenylene sulfide molecular asterisk has ${ }^{1} \mathrm{H}$ NMR signals in the range of 7.37 to $6.79 \mathrm{ppm} .{ }^{20}$ The theoretically calculated $\delta$ values range 7.1 to $6.8 \mathrm{ppm}$, which are in good agreement with observed ones. Theoretical ${ }^{1} \mathrm{H}$ NMR values were estimated using CS Chem $3 \mathrm{D}^{\circledR}$ ver. 5.0 of CambridgeSoft. The data was tabulated in Table I.

XRD study of core I compound presents the major crystalline peaks at $2 \theta$ angles of $11.48,11.98,12.72$, 16.49 , and $19.25^{\circ}$, indicating the high crystalloid of core I compound in nature. However, XRD patterns of core II to fourth generation poly(phenylene sulfide) dendrimer show broad peak $2 \theta$ at 24.08 (core II), 24.40 (G1), 23.46 (G2), 23.53 (G3), 23.89 (G4), respectively, as seen in Figure 2. The crystallinity was estimated from the comparison of the broad peak area as crystalline region with the remaining area as amorphous region, as presented for first generation poly(phenylene sulfide) dendrimer in insert in Figure 2. Numerical values are listed in Table I. The linear poly(phenylene sulfide) is highly crystallized with $70 \%$ crystallinity, ${ }^{28,29}$ and hyperbranched poly(phenylene sulfide) is 35\% crystalline and 65\% amorphous. ${ }^{19}$ On the other hand, poly(phenylene sulfide) dendrimers from first to fourth generation decrease their crystallinity from 42 to $25 \%$. This means that the poly(phenylene sulfide) dendrimers are semi-crystalline in nature. Steric crowding may be the possible reason for less crystallinity in higher homologues of

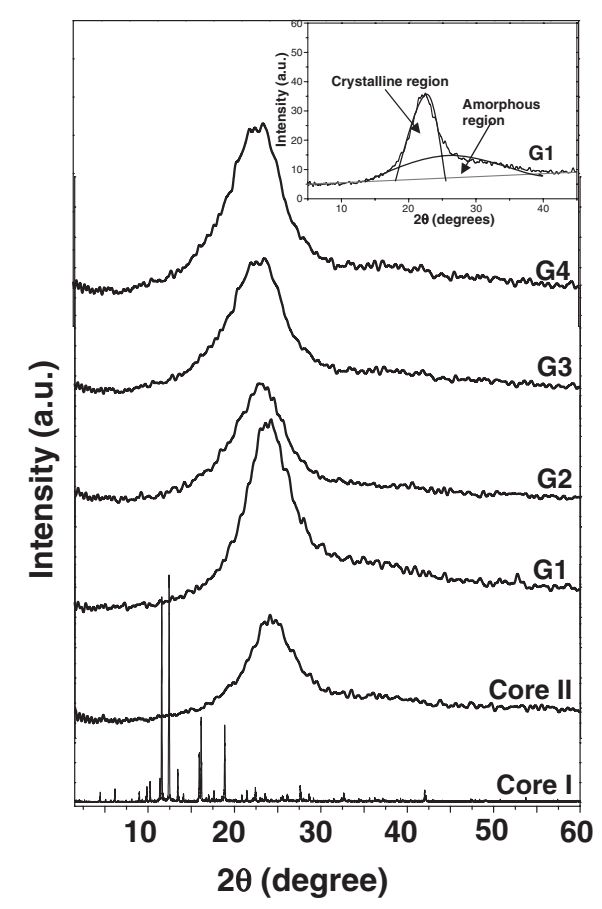

Figure 2. XRD of core I to fourth generation poly(phenylene sulfide) dendrimer. Insert shows composition of crystalline and amorphous regions of first generation poly(phenylene sulfide) dendrimer. poly(phenylene sulfide) dendrimers.

\section{Synthesis of Carboxy Focal Poly(phenylene sulfide) Dendrons}

Carboxy focal poly(phenylene sulfide) dendron up to second generation was synthesized by divergent method. 3,5-dichlorobenzoicacid was employed as starting material and it was converted to 3,5-dithiobenzoicacid (dithiol-1) by reacting with sodium hydrosulfide in polar aprotic solvents such as $\mathrm{N}$-methylpyrrolidone at high temperatures. The formed dithiol1 was isolated under inert conditions to avoid any oxidation and coupling reactions. Further, it was condensed nucleophilically with 3,5-dichlorobromobenzene in dimethylformamide solvent to form the first generation carboxy focal poly(phenylene sulfide) dendron (den-1). The reaction scheme is presented in Scheme 2. Second generation carboxy focal poly(phenylene sulfide) dendron (den-2) was synthesized by converting den-1 to corresponding dithiol-2 and nucleophilically condensed with dichlorobromobenzene. The quantitative yields in each synthetic step were in the range of 60 to $90 \%$.

The UV-vis spectrum of dithiol-1 displayed absorption bands at 248, 287 and $298 \mathrm{~nm}$, respectively, while an extinction coefficient value of a main band $(287 \mathrm{~nm})$ was $3952 \mathrm{~cm}^{2} \mathrm{~mol}^{-1}$. The excitation at $248 \mathrm{~nm}$ produced a fluorescence emission band at $390 \mathrm{~nm}$. UV-vis spectra of den-1 display bands at 241, 262 and $288 \mathrm{~nm}$, whereas den-2 had 263 and $286 \mathrm{~nm}$ band. Extinction coefficient value increased from $3952 \mathrm{~cm}^{2} \mathrm{~mol}^{-1}$ of dithiol-1 to $9524 \mathrm{~cm}^{2} \mathrm{~mol}^{-1}$ of den-2. Table II presents UV-vis and fluorescence spectral data, which are comparable with previously reported poly(thioether) dendron. ${ }^{24,25}$

FT-IR spectrum of dithiol-1 shows bands at 3086 and $1708 \mathrm{~cm}^{-1}$ which are assigned to $\mathrm{OH}$ and $\mathrm{C}=\mathrm{O}$ (keto) stretching modes of carboxylic acid, respectively. The band at $2555 \mathrm{~cm}^{-1}$ assigned to thiol stretching mode was also observed. The bands assigned to phenylene ring stretching mode were observed at 1571, 1405 and $1300 \mathrm{~cm}^{-1}$ in the spectra. There is no band observed around $1096 \mathrm{~cm}^{-1}$, indicating the absence of phenyl chloride functional group in the compound. Dithiol-1 is free from oxidized products such as sulfoxide and sulfone because of no bands assigned to sulfoxide at $1163,1323,1032$ and $641 \mathrm{~cm}^{-1}$ as well as no bands to sulfone at 1030 and $1000 \mathrm{~cm}^{-1}$. FTIR spectrum of den-1 compound presents $\mathrm{OH}$ and $\mathrm{C}=\mathrm{O}$ stretching bands at 3060 and $1707 \mathrm{~cm}^{-1}$, respectively, and phenylene stretching bands at 1546, 1401 and $1388 \mathrm{~cm}^{-1}$. It also presents the phenyl chloride stretching band at $1099 \mathrm{~cm}^{-1}$ but no band in the region of 2600 to $2550 \mathrm{~cm}^{-1}$ that would signify the presence of thiol group. FT-IR spectrum of dithiol-2 

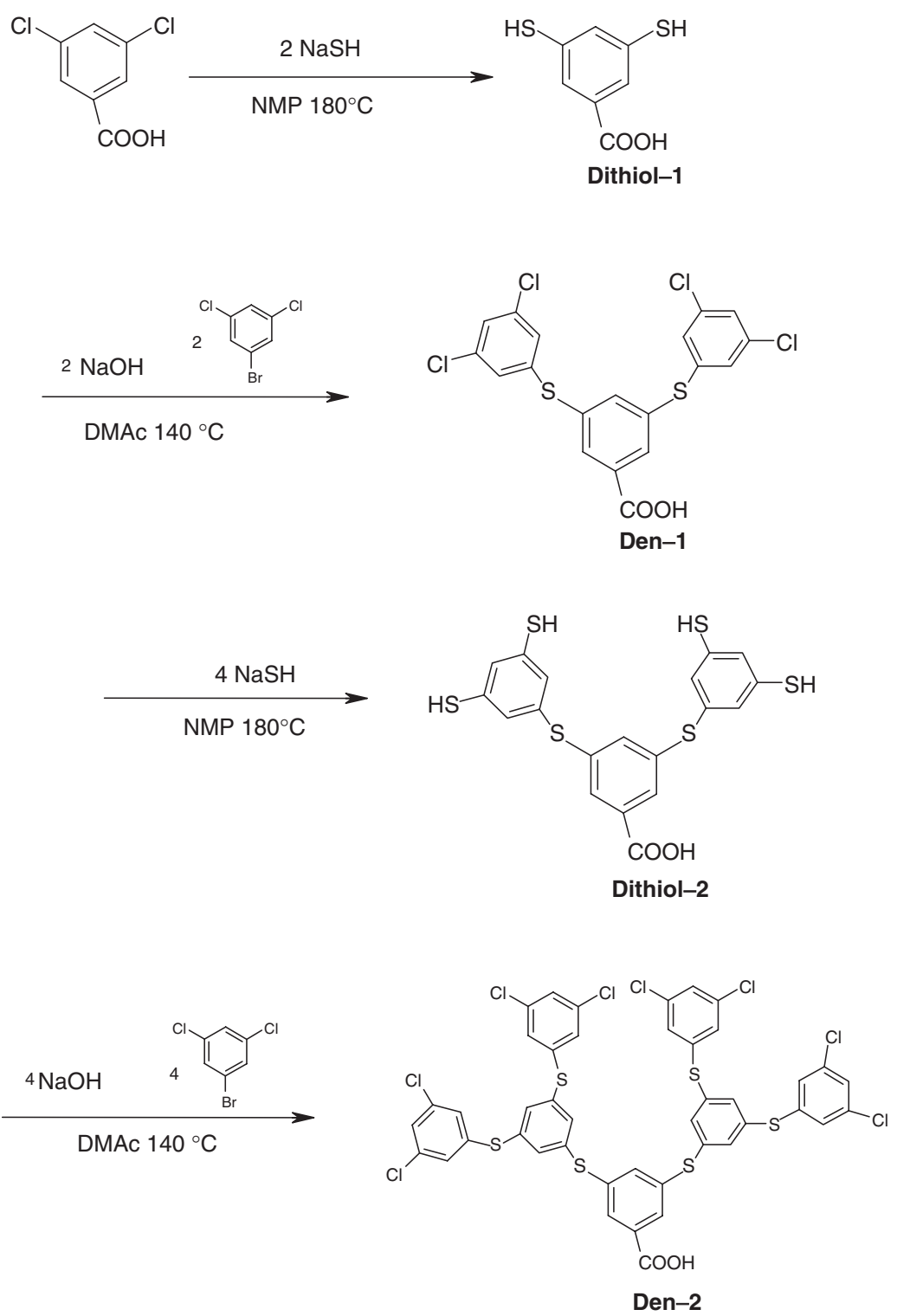

Scheme 2. Synthesis of carboxyl focal poly(phenylene sulfide) dendrons.

shows the $\mathrm{OH}$ and $\mathrm{C}=\mathrm{O}$ stretching bands at 3085 and $1701 \mathrm{~cm}^{-1}$, respectively, and the phenylene stretching bands at 1570 and $1406 \mathrm{~cm}^{-1}$. It also shows the band at $2556 \mathrm{~cm}^{-1}$ for thiol stretching mode and absence of phenyl chloride band at $1096 \mathrm{~cm}^{-1}$. Finally, the den-2 compound presents the significant bands at $3067 \mathrm{~cm}^{-1}$ for $\mathrm{OH}$ stretching mode and at $1703 \mathrm{~cm}^{-1}$ for $\mathrm{C}=\mathrm{O}$ stretching mode, confirming that the acid group is present in the final compound. FT-IR spectrum of den-2 has bands at 1550 and $1405 \mathrm{~cm}^{-1}$ assigned to phenylene stretching modes, and a band at 1097 $\mathrm{cm}^{-1}$ corresponds to a vibrational mode of terminal phenylene chloride group. Elemental analysis of PPS dendron agrees with theoretical values as expected for the structure.

The ${ }^{1} \mathrm{H}$ NMR spectrum of dithiol-1 presents signals at $3.91 \mathrm{ppm}$ corresponding to thiol group, while the phenylene protons at 7.95 and $7.58 \mathrm{ppm}$ and carboxyl- ic acid proton at $10.3 \mathrm{ppm}$. Similarly the ${ }^{1} \mathrm{H}$ NMR spectra of other compounds (den-1 and dithiol-2) present signals in the range of 7.95 to $7.17 \mathrm{ppm}$ for phenylene protons and $10.2 \mathrm{ppm}$ for carboxylic acid proton. ${ }^{1} \mathrm{H}$ NMR spectrum of den-2 shows aromatic protons at 7.31 to $7.15 \mathrm{ppm}$ which are in good agreement with theoretical values at 7.02 to $6.88 \mathrm{ppm}$. The carboxylic acid proton appeared at $10.3 \mathrm{ppm}$. The theoretically calculated $\delta$ values range 8.2 to $7.2 \mathrm{ppm}$, which are in good agreement with observed ones. Theoretical ${ }^{1} \mathrm{H}$ NMR values were estimated using CS Chem 3D ${ }^{\circledR}$ ver. 5.0 of CambridgeSoft. The data was tabulated in Table II.

The molecular weight of den-1 and den-2 was estimated by titration with standard alkali solution, using phenolphthalein as an indicator, as reported for imides and enols in non aqueous solvents by Frietz et al. ${ }^{29}$ 
Table II. UV-vis absorption and fluorescence spectra and ${ }^{1} \mathrm{H}$ NMR of carboxy focal poly(phenylene sulfide) dendron

\begin{tabular}{|c|c|c|c|c|}
\hline Compound & $\begin{array}{c}\text { UV-vis } \\
\lambda_{\max }(\mathrm{nm})^{\mathrm{a}}\end{array}$ & $\begin{array}{c}\varepsilon \\
\left(\mathrm{cm}^{2} \mathrm{~mol}^{-1}\right)^{\mathrm{a}}\end{array}$ & $\begin{array}{c}\text { Florescence } \\
\lambda_{\max }(\mathrm{nm})^{\mathrm{b}}\end{array}$ & $\begin{array}{l}{ }^{1} \mathrm{H} \text { NMR } \\
\delta(\mathrm{ppm})^{\mathrm{c}}\end{array}$ \\
\hline Dithiol-1 & $248,287,298$ & $3952(287 \mathrm{~nm})$ & 390 & $\begin{array}{l}10.3(1 \mathrm{H}), \\
7.95(\mathrm{~d}, 2 \mathrm{H}), \\
7.58(\mathrm{t}, 1 \mathrm{H}), \\
3.91(\mathrm{~s}, 2 \mathrm{H})\end{array}$ \\
\hline Den-1 & $241,262,288$ & $4560(262 \mathrm{~nm})$ & 387 & $\begin{array}{c}10.2(1 \mathrm{H}), \\
7.39(\mathrm{~s}, 2 \mathrm{H}), \\
7.32-7.24(\mathrm{~m}, 4 \mathrm{H}), \\
7.25-7.21(\mathrm{~m}, 2 \mathrm{H}), \\
7.17(\mathrm{~s}, 1 \mathrm{H})\end{array}$ \\
\hline Dithiol-2 & 261,285 & $8962(261 \mathrm{~nm})$ & 383 & $\begin{array}{c}10.3(1 \mathrm{H}), \\
7.95-7.94(\mathrm{~d}, 3 \mathrm{H}), \\
7.58-7.57(\mathrm{t}, 6 \mathrm{H}), \\
3.95(\mathrm{~m}, 4 \mathrm{H})\end{array}$ \\
\hline Den-2 & 263,286 & $9524(263 \mathrm{~nm})$ & 379 & $\begin{array}{c}10.3(1 \mathrm{H}), \\
7.32(\mathrm{~s}, 2 \mathrm{H}), \\
7.31-7.24(\mathrm{~m}, 8 \mathrm{H}), \\
7.24-7.17(\mathrm{~m}, 7 \mathrm{H}), \\
7.16(\mathrm{~s}, 2 \mathrm{H}), \\
7.15(\mathrm{~s}, 2 \mathrm{H})\end{array}$ \\
\hline
\end{tabular}

${ }^{\mathrm{a}} 1 \mathrm{mg} \mathrm{cm}^{-3}$ in chloroform. ${ }^{\mathrm{b}} 1 \mathrm{mg} \mathrm{cm}^{-3}$ in dichloromethane. ${ }^{\mathrm{c}} 1 \mathrm{mg} \mathrm{cm}^{-3}$ in deuterated chloroform

\section{Langmuir Film at Air/Water Interface}

Third generation poly(phenylene sulfide) dendrimer (G3) with high hydrophobicity in nature and second generation carboxy focal poly(phenylene sulfide) dendron (den-2) with hydrophobic periphery and hydrophilic focal point were selected for studying monolayer formation at air/water interface. The results obtained could deeply provide helpful information to understand the molecular-assembling mechanism of dendrimers and dendrons at the air-water interface, which is important to the fabrication of highly ordered films of dendritic polymers.

Surface pressure-area $(\pi-\mathrm{A})$ isotherms at air-water interface at $25^{\circ} \mathrm{C}$ are presented in Figure 3 for G3 and den-2. The Langmuir film of G3 is stable at least up to $24 \mathrm{mN} \mathrm{m}^{-1}$ without the collapse of the film. It displayed liquid and solid phases. The den-2 has similar isotherm characterized by an increase of the surface pressure up to $32 \mathrm{mN} \mathrm{m}^{-1}$, followed by the collapse of the film. The occupied molecular area of G3 and den-2 estimated from these $\pi-\mathrm{A}$ isotherms by extrapolating the linear solid phase region to zero pressure were 0.83 and $0.10 \mathrm{~nm}^{2}$ molecule ${ }^{-1}$ respectively. The hysteresis behavior of G3 was observed by repeating the compression/expansion cycle. Figure 3 shows relatively smaller area per molecule in expansion than compression and in the second compression than the first compression, while the third compression/expansion cycle passed same process with the second. This suggests the rearrangement of G3 mole- cules during compression/expansion process. On the other hand, remarkable hysteresis was not seen for a case of den-2.

The occupied surface area may depend on chemical structure, rigidity, and steric interaction of molecules. Assuming disclike shape of G3 molecule with $2.34 \mathrm{~nm}$ radius and $1.27 \mathrm{~nm}$ thickness, the calculated surface areas per molecule are 17.20 and $2.98 \mathrm{~nm}^{2}$ molecule ${ }^{-1}$ for parallel and perpendicular arrangements, respectively, of G3 to aqueous subphase. The occupied molecular area $\left(0.83 \mathrm{~nm}^{2}\right.$ molecule $\left.{ }^{-1}\right)$ at the first compression is smaller than both of them. This indicates the compacting or accumulating of G3 molecules in Langmuir film at air/water interface. The occupied molecular area $\left(0.69 \mathrm{~nm}^{2}\right.$ molecule $\left.{ }^{-1}\right)$ at the second compression was decreased, suggesting the reinforcement of such phenomenon.

Similarly, considering rectangular pyramid shape of den-2 with $1.28 \times 0.80 \mathrm{~nm}^{2}$ base and $1.53 \mathrm{~nm}$ height and molecular arrangement of inverse pyramid to aqueous subphase, the calculated value of occupied molecular area is $1.12 \mathrm{~nm}^{2}$ molecule ${ }^{-1}$. The observed value $\left(0.10 \mathrm{~nm}^{2}\right.$ molecule $\left.{ }^{-1}\right)$ is considerably smaller than the dimension of the den-2 molecule. Dissolution or aggregation of the film-forming compound may cause such decrease of occupied molecular area. In the case of den-2, one may discount the possibility of the dissolution in the subphase, because den-2 is insoluble in water. Then it is expected that molecules aggregate on the subphase surface. 

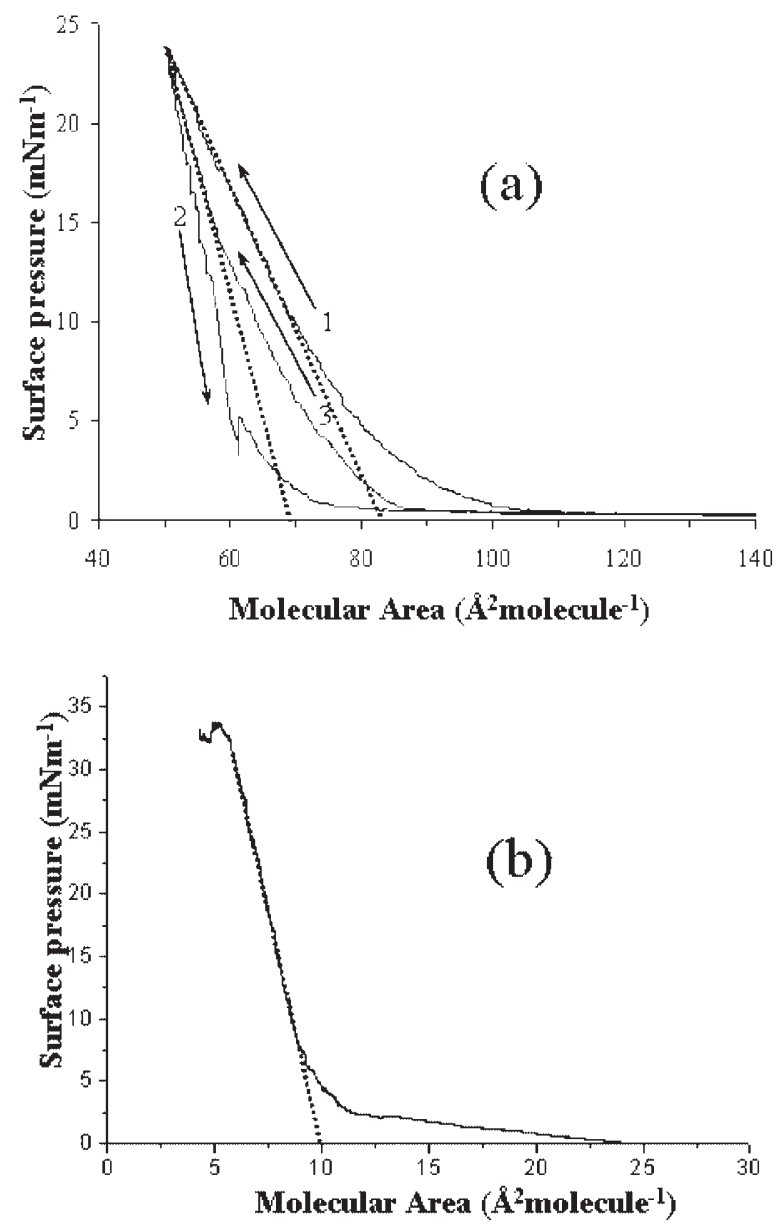

Figure 3. Surface pressure-area isotherm at air-water interface at $25^{\circ} \mathrm{C}$. (a) Third generation poly (phenylene sulfide) dendrimer. 1) First compression 2) first expansion 3) second compression. (b) Second generation poly(phenylene sulfide) dendron. Dotted straight lines are extrapolation of solid phase region to zero pressure.

\section{$L B$ and Adsorption Films on Solid Substrate}

In comparison with Langmuir film at air/water interface, thin films of dendrimer and dendron were fabricated on solid substrate by LB and adsorption technologies, which can offer means to control molecular order and orientation in the films. LB films of G3 and den-2 were formed on mica surface by transferring Langmuir film at air/water interface. Separately, G3 and den-2 were adsorbed for $15 \mathrm{~min}$ on mica surface from a $10 \mathrm{mg} \mathrm{cm}^{-3}$ solution in chloroform. The surface morphology of the films was investigated by AFM observations.

An AFM image and section analysis (Figure 4) of the LB film of G3 revealed layer structure with height difference of $5 \mathrm{~nm}$ and surface roughness of $1.5 \mathrm{~nm}$. About one-third of the layer were occupied by holes or defects. The observed height difference is just a diameter of disclike G3 molecule. Then the perpendicular orientation of discs to the substrate is supported. In order to explain the smaller (one-fourth times) occu-
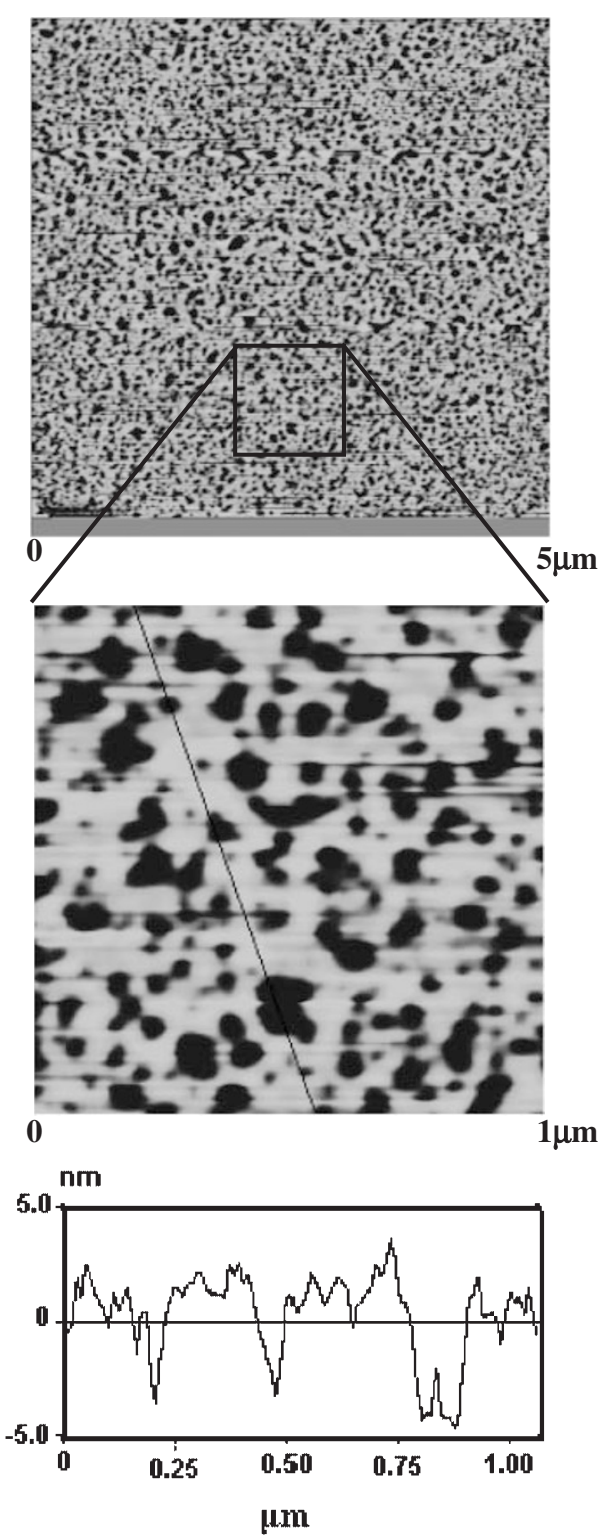

Figure 4. AFM images and section analysis of monolayer LB film of third generation poly(phenylene sulfide) dendrimer.

pied surface area obtained from $\pi-\mathrm{A}$ isotherm, the molecular layer must be accumulated rather than molecules become compact, if considering the holes or defects of the layer. In the meanwhile, an AFM image (Figure 5) of the adsorption film of G3 displayed flatter surface with height difference of only $2.5 \mathrm{~nm}$. It is assumed that although monolayer of G3 molecules is a unit of observed layer, molecular arrangement should be different from LB film.

AFM image and section analysis of den-2 LB film are shown in Figure 6. They presented oval shaped unidirectional domains with $75 \mathrm{~nm}$ height and 1.25 $\mu \mathrm{m}$ width. After annealing the sample at $40^{\circ} \mathrm{C}$ for $2 \mathrm{~h}$, height of domains reduced to $37 \mathrm{~nm}$. This supports the result from $\pi-\mathrm{A}$ isotherm, that is, den-2 molecules aggregate on the subphase surface, since the maximum domain height is 5 times higher than 

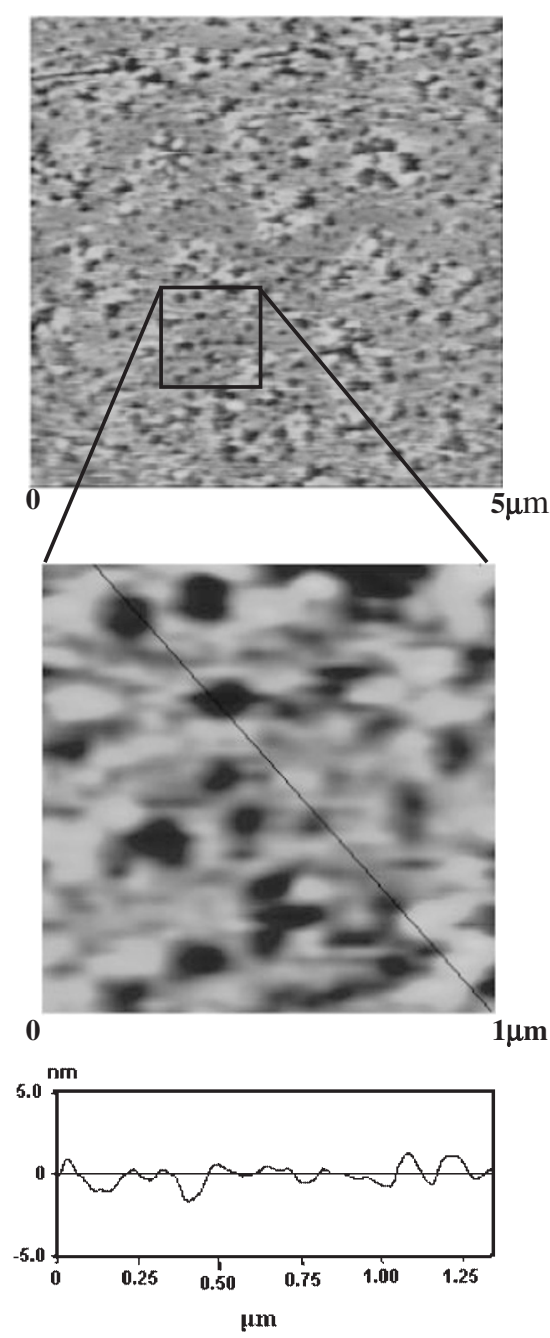

Figure 5. AFM images and section analysis of adsorption film of third generation poly(phenylene sulfide) dendrimer. molecular height. An AFM image of den-2 adsorption film in Figure 7 displayed flatter surface with $1.5 \mathrm{~nm}$ roughness. Annealing the film at $40^{\circ} \mathrm{C}$ for $2 \mathrm{~h}$, it formed large irregularly shaped layered domains with height of $1.7 \mathrm{~nm}$, indicating monolayer formation. Similar temperature dependence was observed at higher temperature than $40^{\circ} \mathrm{C}$.

On the basis of results presented above, schematic models of molecular organization in LB and adsorption films of G3 and den-2 are depicted in Figure 8. For G3 LB film it can be supposed that disclike molecules are arranged perpendicular to mica surface, aggregate due to face-to-face interaction within two dimensional plane and make a couple due to edgeto-edge interaction in the perpendicular direction. Ordered film has some defects of the organization of molecules. The face-to-face and edge-to-edge interactions are owing to strong phenyl ring $\pi-\pi$ stacking. The face-to-face interaction is also motive force for the molecular arrangement in the adsorption film. However, ordering is not uniform over whole surface and molecules tilt with $\sim 60^{\circ}$ angle from normal direction on the surface. The aggregation due to the $\pi-\pi$ stacking interaction has been assumed for linear poly(phenylene sulphide). ${ }^{28}$

In a case of den-2 LB film, carboxylic acid focal point in pyramidal shape molecule attaches to mica surface. The aggregation can be formed by the faceto-face interaction of dendrons within two dimensional plane and the repeating accumulation by the $\pi-\pi$ stacking interaction between phenylene terminal groups and the hydrophilic interaction between focal (a) before annealing
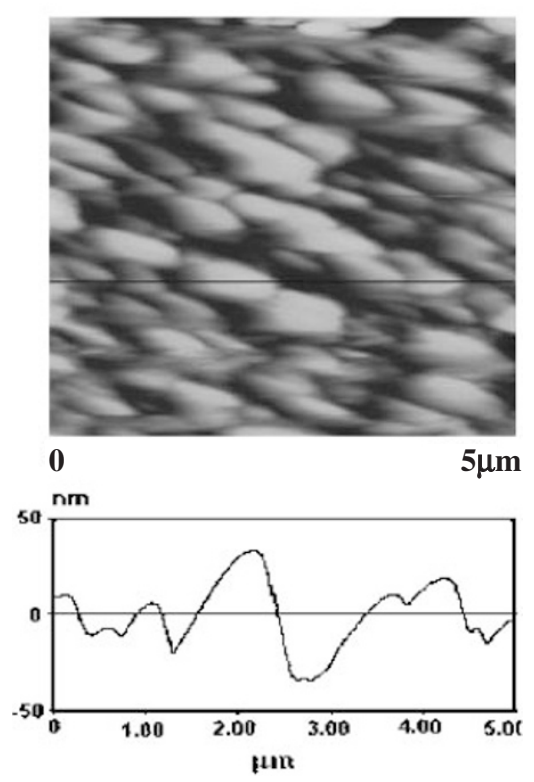

(b) after annealing
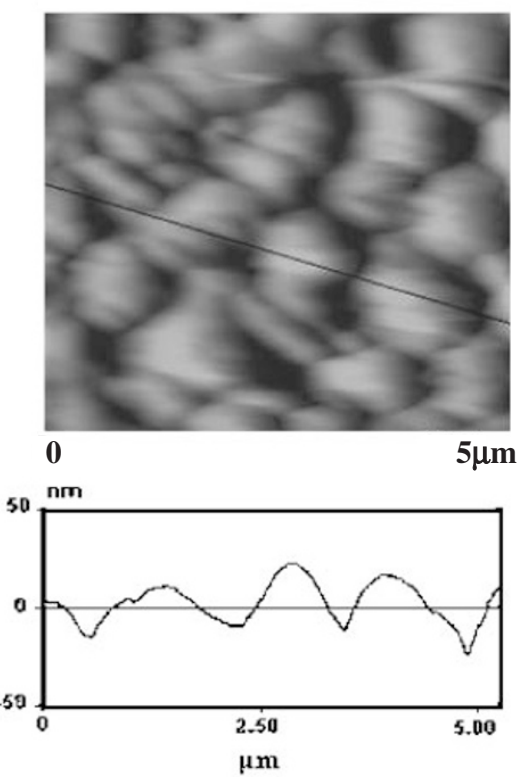

Figure 6. AFM images and section analyses of monolayer LB film of second generation poly(phenylene sulfide) dendron. (a) Before annealing (b) after annealing at $40^{\circ} \mathrm{C}$ for $2 \mathrm{~h}$. 
(a) before annealing

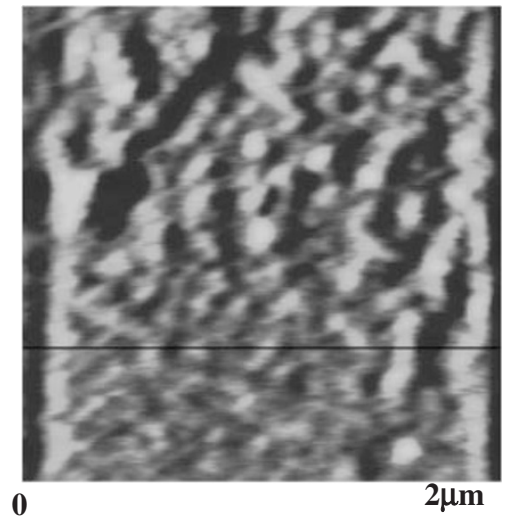

(b) after annealing

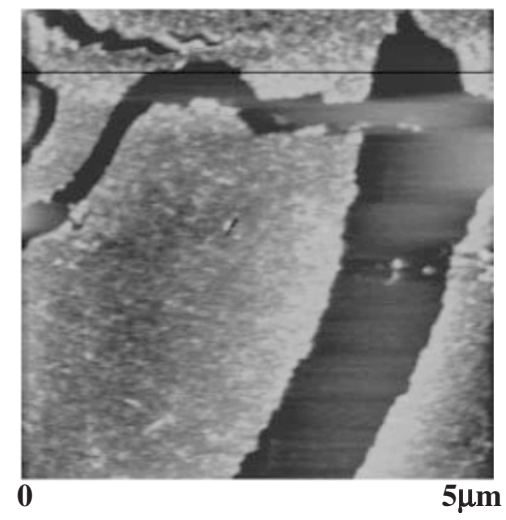

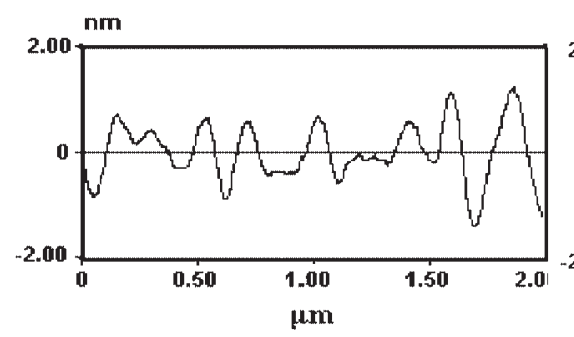

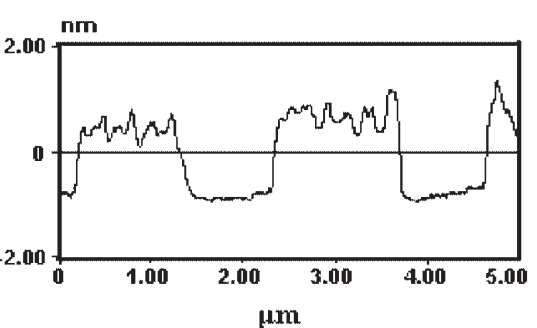

Figure 7. AFM images and section analyses of adsorption film of second generation poly(phenylene sulfide) dendron. (a) Before annealing (b) after annealing at $40^{\circ} \mathrm{C}$ for $2 \mathrm{~h}$.

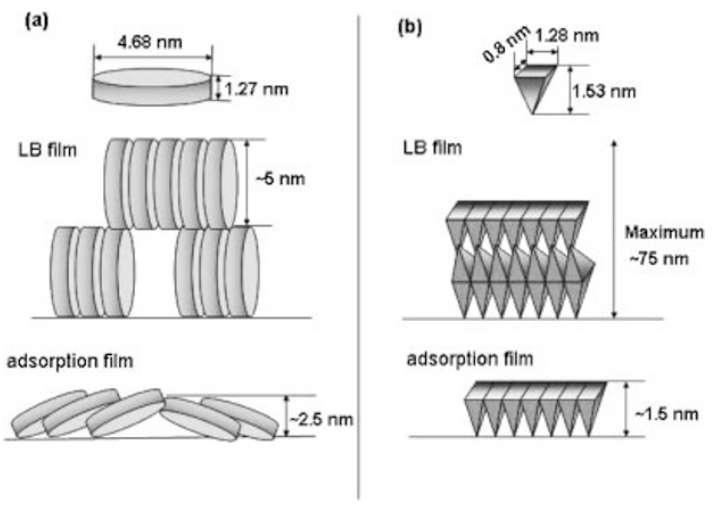

Figure 8. Schematic illustration of possible arrangement of polymers in LB and adsorption films. (a) Third generation poly(phenylene sulfide) dendrimer (b) second generation poly(phenylene sulfide) dendron.

points, forming large domains. In contrast with LB film, den-2 adsorption film is self-assembled monolayer, where den-2 is fixed at its focal point to the substrate. The ordering within 2 dimensional plane was promoted by thermo-annealing.

The film formation of poly(phenylene sulfide) dendrimer is in contrast with a case of poly(benzylether) type dendron. ${ }^{31-33}$ Carboxylic acid focal poly(benzylether) dendrons formed Langmuir monolayer at air/ water interface and AFM image showed discotic monolayer domains in the LB film of second generation. ${ }^{31,32}$ Adsorption behavior has been investigated by thiol focal benzylether type dendron. ${ }^{31}$ Thiol dendron was fabricated into uniform self-assembled monolayer at room temperature. However, multilayer aggregation or accumulation of both dendrons in the normal direction to the surface has never been reported, different from poly(phenylene sulfide) dendron. This may result from the weaker $\pi-\pi$ stacking interaction between benzyl groups in poly(benzylether) dendrons because of longer distance between them. Poly(phenylene sulfide) dendrons are semi crystalline material but poly(benzylether) dendrons are amorphous. The difference of this physical property may also come from the different strength of $\pi-\pi$ stacking interaction.

\section{CONCLUSIONS}

Poly(phenylene sulfide) dendrimers soluble in common organic solvents were synthesized up to fourth generation, and carboxy focal dendron up to second generation were similarly synthesized. LB film of third generation poly(phenylene sulfide) dendrimer presented the multilayer with defects, where molecules are oriented perpendicular to the substrate. On the other hand, its adsorption film was monolayer consisting of tilted molecules. LB film of second generation carboxy focal poly(phenylene sulfide) dendron exhibited the presence of oval shaped large domain structure, that is, the aggregates, while the absorbed 
film was self-assembled monolayer. The film formation of poly(phenylene sulfide) dendron were in contrast with that of poly(benzylether) dendrons.

Acknowledgment. Authors are thankful to Dr. Y. Maeda, Nagoya University Nagoya, Japan, for providing NMR spectra of samples. OY is thankful to $21 \mathrm{st}$ Centaury COE program (No. 14COEB01-00) for the financial support of postdoctoral fellowship.

\section{REFERENCES}

1. L. Yu, M. Chen, and L. R. Dalton, Chem. Mater., 2, 649 (1990).

2. D. A. Tomalia, H. Baker, J. Dewald, M. Hall, G. Kallos, S. Martin, J. Roeck, J. Ryder, and P. Smith, Polym. J., 17, 117 (1985).

3. J.-M. Lehn, "Supramolecular Chemistry, Concepts and Prospectives," VCH, Weinheim, 1995.

4. G. R. Newkome, C. N. Moorefield, and F. Vögtle, "Dendritic Molecules," VCH, Weinheim, 1996.

5. D. A. Tomalia, H. Baker, J. Dewald, M. Hall, G. Kallos, S. Martin, J. Roeck, J. Ryder, and P. Smith, Macromolecules, 19, 2466 (1986).

6. K. Aoi, A. Motoda, M. Ohno, K. Tsutsumiuchi, M. Okada, and T. Imae, Polym. J., 31, 1071 (1997).

7. K. Aoi, A. Motoda, M. Okada, and T. Imae, Macromol. Rapid Commun., 18, 945 (1997).

8. C. J. Hawker and J. M. J. Fréchet, J. Am. Chem. Soc., 112, 7638 (1990).

9. K. L. Wooley, C. J. Hawker, and J. M. J. Fréchet, J. Am. Chem. Soc., 113, 4252 (1991).

10. N. Launay, M. Caminac, R. Lahana, and J. P. Majoral, Angew. Chem., Int. Ed., 33, 1589 (1994).

11. K. Y. Chen and C. B. Gorman, J. Org. Chem., 61, 9229 (1996).

12. J. W. J. Knapen, A. W. vander Made, de J. C. Wilde, P. W. N. M. van Leeuwen, P. Wljkens, D. M. Grove, and G. van Koten, Nature, 372, 659 (1994).

13. R. Roy, Top. Curr. Chem., 187, 254 (1997).
14. N. Jayaraman, S. A. Nepogodiev, and J. F. Stoddart, Chem.-Eur. J., 3, 1193 (1997).

15. P. Ray, D. Zanimi, S. J. Meunier, and A. Romanowska, ACS Symp. Ser., 560, 104 (1994).

16. R. G. Nuzzo and D. L. Allara, J. Am. Chem. Soc., 105, 4481 (1983).

17. L. Zhang, F. Huo, Z. Wang, L. Wu, X. Zhang, S. Hoppener, L. Chi, H. Fuchs, J. Zhao, L. Niu, and S. Dong, Langmuir, 16, 3813 (2000).

18. M. Jikei, Z. Hu, M. Kakimoto, and Y. Imai, Macromolecules, 29, 1062 (1996).

19. O. Yemul and T. Imae, J. Surf. Sci. Technol., 19, 117 (2003).

20. M. Gingras, A. Pinchart, and C. Dallaire, Angew. Chem., Int. Ed., 110, 3338 (1998).

21. M. Gingras, A. Pinchart, C. Dallaire, T. Mallah, and E. Levillain, Chem.-Eur. J., 10, 2895 (2004).

22. J. R. Campbell, J. Org. Chem., 29, 1830 (1964).

23. A. P. West Jr., D. Van Engen, and R. A. Pascal Jr., J. Am. Chem. Soc., 111, 6846 (1989).

24. A. V. Bierbeek and M. Gingras, Tetrahedron Lett., 39, 6283 (1998).

25. A. Dahan, A. Weissberg, and M. Portnoy, Chem. Commun., 10, 1206 (2003).

26. D. A. Zimmerman, J. L. Koenig, and H. Ishida, Spectrochim. Acta A, 51, 2397 (1995).

27. C. J. Pouchert, Ed., "The Aldrich Library of Infrared Spectra, 3rd ed," Aldrich Chemical Co., Inc., Milwaukee, WI, 1981.

28. L. C. Lopez and G. L. Wilkes, J. Macromol. Sci., Part C: Rev. Macromol. Chem. Phys., 29, 83 (1989).

29. S. O. Yemul, O. S. Yemul, S. Ponrathnam, C. R. Rajan, and A. Fradet, Macrmol. Rapid Commun., 19, 635 (1998).

30. J. S. Fritz, Anal. Chem., 24, 674 (1952).

31. L. Zhang, F. Huo, Z. Wang, L. Wu, X. Zhang, S. Höppener, L. Chi, H. Fuchs, J. Zhao, L. Niu, and S. Dong, Langmuir, 16, 3813 (2000).

32. S. Xu, S. Kang, G. Deng, P. Wu, Q. Fan, C. Wang, C. Wan, and C. Bai, Chem. Lett., 32, 290 (2003).

33. S. Kang, S. Xu, G. Deng, P. Wu, Q. Fan, C. Wang, L. Wanand, and C. Bai, Chem. Phys. Lett., 370, 542 (2003). 